\title{
Researching, Planning, and the Implementation of Tāłtān Language Nests: Sharing our Experiences
}

\author{
Edōsdi / Judy Thompson \\ University of Northern British Columbia \\ judy.thompson@unbc.ca \\ Gileh / Odelia Dennis \\ deaselanguage@tahltan.org \\ Shāwekāw / Patricia Louie \\ iskutlanguage@tahltan.org
}

\begin{abstract}
Since 2012, our nation has been working to revitalize and reclaim our language, with an emphasis on the creation of new speakers. Tahltan Elders have spoken about the importance of our young children learning our language, so a focus has been on teaching babies and toddlers in language nests. A language nest is a home-like environment for infants to learn the language in an immersion setting and provides opportunities for all generations to be part of the revitalization of a language. One of the authors carried out research that focused on Tahltan community experiences of language revitalization. The investigation focused on language revitalization's connection to health and healing and what needs to be done to revitalize our language. Following recommendations from that research, language nests have been one of the vital components our Language and Culture Program has focused on. The ways in which community members in Tahltan communities have planned and implemented language nests will be discussed, along with sharing experiences and activities that are currently being carried out.
\end{abstract}

Keywords: Indigenous language revitalization, Tahltan, language nests, child language acquisition

\section{Introduction}

Yet no matter what we do, aspire to do or fail to do, we remain steadfast and loyal to one rule, one rule only: teach our children to speak the Blackfoot language. It is our holy mantra, the sacred counsel of all our actions, planning and thinking. Teach our children to speak the Blackfoot language, because the transference of our language to our children must have precedent over everything else. Without children speaking your tribal language fluently nothing else will ultimately matter. The most sophisticated computer program cannot mimic the genius of a child speaking their tribal language. True tribal language revitalization ultimately rests with our children's ability to fill the abyss of language loss today in our tribal communities (Kipp, 2009, p. 2).

We agree with these wise words of the late Blackfoot scholar Darrell Kipp. Our Elders also echo these sentiments about the need to have our babies and toddlers speaking our language (Edōsdi, 
2012). Research carried out by Edōsdi (2012) focused on community experiences of language revitalization and has also guided our decision to create opportunities for our young children to be immersed in our language. Conversations with Tahltan co-researchers (fluent speakers, language teachers, educators, administrators, and language learners) informed the investigation with their ideas and experiences regarding Tāłtān language revitalization. The investigation focused on how language revitalization is connected to health and healing, as well as researching what has been done and what still needs to be done to revitalize the Tātān language. From what was learned from co-researchers, scholars who have worked with our communities, Indigenous community language revitalization experts, and international language revitalization scholars, language nests have been one of the key programs that the Tahltan Language and Culture Program has focused on. Language experts (Fishman, 1996; Lee, 1996; Stiles, 1997) have indicated that the first few years of a child's life are critical in mastering the basic sound system and grammar of a language. A language nest not only provides a home-like environment for infants to learn the language in an immersion setting, it creates opportunities for parents to learn the language along with their children. It provides opportunities for Elders to be involved in the revitalization of our language, and for adult second language learners to increase their proficiency in the language. Our language connects us to our Ancestors, our worldview, our land, and our culture. Our language is who we are. By connecting our babies to our Ancestors and providing the opportunities for all generations to be part of the revitalization of our language, we are starting a process in which we begin to heal from the impacts of colonization and assimilation by reclamation of our language, culture, and identity. Therefore, we are allowing our voices to become stronger and healthier (Edōsdi, 2012).

There are three Tahltan communities: Łuwechōn (Iskut), Tātl'ah (Dease Lake), and Tlēgo'īn (Telegraph Creek). The driving distance between Łuwechōn and Tātl'ah is 84 km and between Tātl'ah and Tlēgo'īn, 108 km.

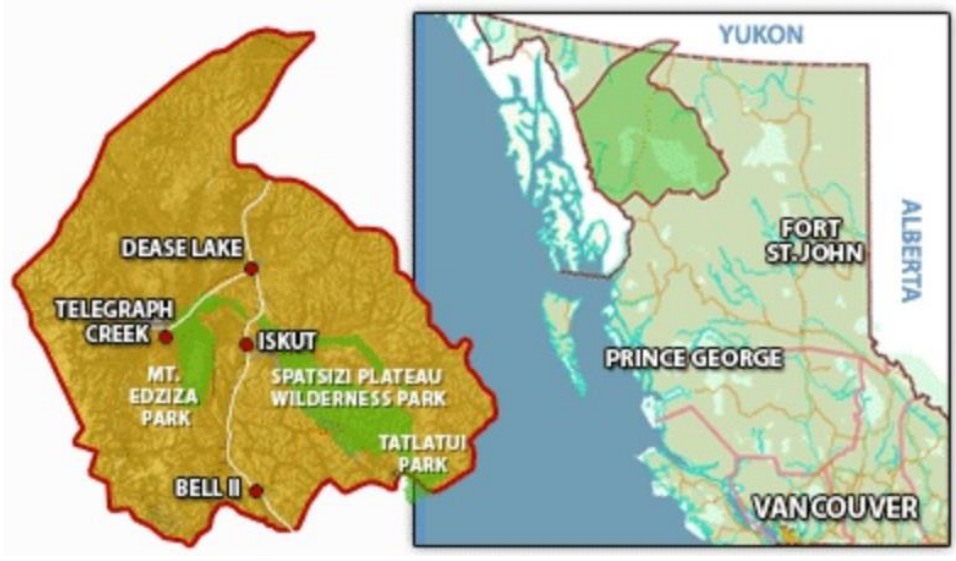

Figure 1. Map of Tahltan Communities (Luwechōn - Iskut, Tātl'ah - Dease Lake, Tlēgo'inn - Telegraph Creek) and Territory in British Columbia

(Image from https://warriorpublications.wordpress.com/2012/12/18/b-c-s-sacredheadwaters-to-remain-protected-from-drilling/tahltan-territory-map/)

Cultural and Pedagogical Inquiry, Fall 2018, 10(2), pp. 64-83

ISSN 1916-3460 @ 2018 University of Alberta

http://ejournals.library.ualberta.ca/index.php/cpi/index 
We opened our first nest, Dzimēs Chō T'oh (Swainson's Thrush's Nest), in Łuwechōn in May 2014, our second nest, K'asba'e T'oh (Ptarmigan's Nest), in December 2014 in Tātl'ah, with plans to open a nest, Mesk'ā T'oh (Seagull's Nest), in Tlēgo'īn. The ways in which community members in Tahltan communities have planned and implemented language nests will be discussed, with sharing examples of experiences and activities that are being carried out in our nests. Each of our stories about language nest work will be interspersed throughout the paper, depending on our areas of knowledge, expertise, and experience.

\section{Location and Presentation of our Voices}

We have been learning our language, stories, culture, worldview - where we fit as Tahltan people in this world - from our Elders. It is important for us to introduce ourselves - to locate ourselves - to tell you who we are as Tahltan women, before we share our language nest stories with you.

\section{Edōsdi}

Edōsdi ushye. Tałsetān didene hots'iye esdāts'ēhi. Tlabāne de'ots'ih ja' sini. Tsesk'iye esdāts'ēhi. My name is Edōsdi, which means "someone who raises up children and pets" or more simply, someone who is a teacher. My English name is Judy Thompson, and I am Tahltan from the Tsesk'iye (Crow) Clan. I was given my name from estsū Julia Callbreath and her cousin Robert Quock. Edōsdi was the name of estū Julia's mother's edē, Susie Tashoots (nee Quock). Edōsdi is a Tsesk'iye name, and belongs to the Tlabāne territory, one of three Tsesk'iye territories. My name connects me directly to the land.

Over the last three decades, I have attempted to learn my language from my grandparents and other Tahltan Elders. My passion is the revitalization of our language. I am hungry for my language and I have made it one of my life's goals to increase my proficiency. I am currently working closely with one of our fluent speakers, Jenny Quock, to be immersed in the language. I want to experience our people's ways of knowing, our worldview, our way of life, through our language. Didene ekune mehōdihi eku desijihi.

\section{Odelia Dennis}

Odelia Dennis ushye. Dīdenek'eh eszi' Gileh. Tahltan ja'ast'īn, Tl'abāne de'ots'ih ja sini. Ch'iyone esdāts'ēhi. My name is Odelia Dennis. My traditional name is Gileh, which I received from estsiye Loveman Nole. Gileh was estsū Winnifred Quock's sister Julie's traditional name. I am Tahltan from the Tl'abāne territory. I belong to the Ch'iyone (Wolf) Clan.

I am a second language learner of the Tāłtān language. My increased proficiency is due to the fluent speakers and Elders who have taught me the language well. Soga kesehedī. I teach in K'asba'e T'oh (Ptarmigan's Nest) and in the University of Victoria's Diploma in Indigenous Language Revitalization Program. Every day I strive to be a better teacher and better at showing appreciation to the fluent speakers of our nation.

\section{Patricia Louie}

Dīdenek’eh eszi Shāwekāw. Estu Nellie Quock eszi yeghāni’ān. Esdātsehi estu Mary Ward Atlin hots'ih. Ch'iyone esdāts'ēhi, Łuwechōn nasdē. English eszi, Patricia Louie ushye. My native name is Shāwekāw, which is the name my grandma Nellie Quock gave me. My great 
grandmother is Mary Ward from Atlin. I belong to the Ch'iyone Clan and I live in Łuwechōn. My English name is Patricia Louie.

I began working in 2014 at Dzimes Chō T'oh (Swainson's Thrush's nest) in Łuwechōn with very little language, which is when my journey of discovering who I am began. First and foremost, learning Tāłtān is very important to me as I grew up learning the Tahltan culture. My biggest dream is that all our Indigenous brothers and sisters learn their languages. In learning your language, you will find your identity - learn your language and find your power!

\section{Acknowledgement of Who We Learned From}

When our Elders tell a story, it is very common for them to repeatedly mention who shared that knowledge and wisdom with them. Back in 1992, Edōsdi began learning about our clan system from her Aunty Eva Callbreath, her maternal grandfather's sister-in-law. While teaching Edōsdi about the different Ts'eskiye (Crow) and Ch'iyōne (Wolf) groups, several times, she would say "Benny Frank told me about this" or "This is what Benny Frank told me" (as cited in Edōsdi, 2012, p. 50), referring to one of our Tahltan Ancestors. In keeping with the ways our Elders talk about who they have learned from, we need to follow in their footsteps by honouring our teachers who assisted us in getting our nests started and have kept them running.

What we know about language nests has come from what we have learned from Dr. Kathryn Michel (Michel, 2005; Michel, 2012; FPCC, 2014), founder of the Ceseyeten Language Nest in 1987. Language Nest research carried out by Dr. Onowa McIvor (2005; 2006), Dr. Natalie Chambers (2014; 2015), Dr. Eve Okura (2017), and Tahltan educator Kāshā - Julie Morris (2017; 2018), has also informed our learnings. We have also learned from the Māori people through their writings and what they have shared with other language champions, such as Dr. Kathryn Michel, who have then passed that knowledge and wisdom onto us and others. In 2015, Tāłtān Language teacher and fluent speaker Angela Dennis, Edōsdi, and Odelia Dennis took part in the He 'Ōlelo Ola, Hilo Field School Study in which they visited the Hilo 'Aha Pūnana Leo infant toddler and preschool program (Pūnana Leo o Hilo/Hi'ipēpē), as well as the Nāwahīokalani'ōpu'u K-12 Hawaiian medium program, and the Ka Haka 'Ula O Ke'elōlani College of Hawaiian Language degree programs.

We must emphasize that without the support, knowledge, wisdom, and guidance from Dr. Kathryn Michel, we would not have been able to open our nests in the way we have. From Kathy's guidance, we have, to-date, opened two language nests, with plans to open a third.

As part of her doctoral research, Edōsdi $(2012,2018)$ developed a Tahltan Language and Culture Framework that highlights four areas that we need to focus on to revitalize and reclaim our language (Governance, Programs, Documentation, Training and Professional Development) while also focusing on the healing, wellbeing, and resilience of our people in relationship to language revitalization.

Cultural and Pedagogical Inquiry, Fall 2018, 10(2), pp. 64-83

ISSN 1916-3460 @ 2018 University of Alberta

http://ejournals.library.ualberta.ca/index.php/cpi/index 


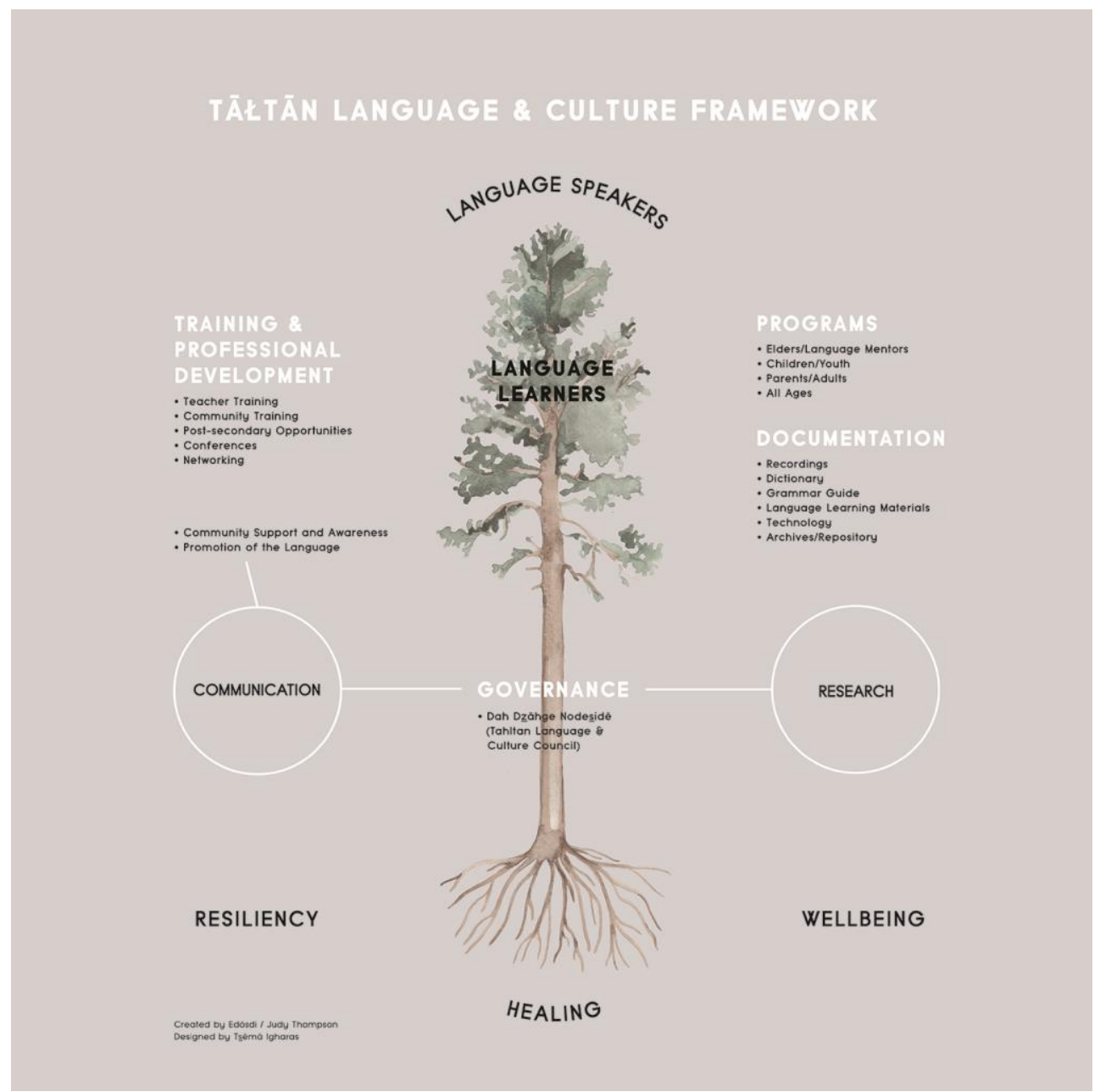

\section{Figure 2. Tahltan Language and Culture Framework. Created by Edōsdi, Designed by Tsēema Igharas (Tahltan Artist)}

In keeping with our Tahltan Language and Culture Framework (TCC, 2013; TCG, 2018), we are sharing our experiences to both support and promote the critical need to revitalize all Indigenous languages, which is our right as Indigenous peoples. Article 13 of the United Nations Declaration of the Rights of Indigenous Peoples (United Nations, 2008) states, "Indigenous peoples have the right to revitalize, use, develop and transmit to future generations their histories, languages, oral traditions, philosophies, writing systems and literatures, and to designate and retain their own names for communities, places, and persons" (p. 7). It is also stated by Chambers (2014) that "Indigenous young children have a basic human right to be raised in their heritage language, and this research demonstrates that language nest programs may benefit participating children and Elders" (p. 189). With this paper, we are following in the footsteps of our teachers.

\section{Methodology}

For her doctoral research, Edōsdi articulated a Tahltan methodology, Tahltan Voiceability, which involves: (1) receiving the teachings of our Ancestors and Elders, (2) learning and knowing these teachings, and (3) the sharing of these teachings with our people Cultural and Pedagogical Inquiry, Fall 2018, 10(2), pp. 64-83 
(Edōsdi, 2012; Edōsdi, 2017). In her doctoral dissertation, Edōsdi (2012) used the term "teachings" to name the knowledge and wisdom that was shared with her by her Ancestors, Elders, and other cultural experts over the years.

This methodology has shaped the way in which we gathered the teachings specific to language nests. In terms of Indigenous research, Cree scholar Shawn Wilson (2001) has stated,

Indigenous people need to do Indigenous research because we have the lifelong learning and relationship that goes with it. You are not just gaining information from people; you are sharing your information. You are analyzing and you are building ideas and relationships as well. Research is not just something that's out there: it's something that you're building for yourself and for your community (p. 179).

Regarding Tahltan Voiceability specific to our language nest work, (1) we have received teachings, not only from our Ancestors and Elders, but also from other Indigenous scholars, academics, communities, and nations. (2) We have learned about what needs to be done in opening and operating language nests, and have embodied those teachings. Finally, with this paper, (3) we are not only sharing these teachings with our people, but with all who are interested and need support, in line with our Tahltan Language and Culture Framework (TCC, 2013; TCG, 2018).

\section{State of the Tāltān Language}

When Edōsdi (2012) carried out her doctoral research focusing on Tāłtān language revitalization, as per First Peoples' Council's Framework for Defining and Measuring Language Endangerment, our language fell into the "Critically Endangered - Nearly Extinct" (Amrhein et al., 2010, p. 23) Level of Endangerment, with "Nearly Extinct" being replaced by "Critical" in the 2014 report (Gessner et al., 2014). The criteria for this in terms of speakers is that a language is no longer being learned as a first language by children, is only spoken by the grandparent generation and up, and it is not normally spoken by adults and children except for some individuals who are learning the language (Amrhein et al., 2010). In terms of usage, the criteria are that language usage by Elders is rarely used, and that some language programming may exist. As well, language resources are limited, with it being a challenge to check for accuracy and to have more documentation occurring (Amrhein et al., 2010). Since the beginnings of our Tahltan Language and Culture Program in 2012, we have seen our language moving out of the "Critically Endangered" level into the "Declining" level, with our program working hard to achieve the level of "Thriving". We prefer to look at the state of our language in a positive light, especially since we have been working tirelessly to revitalize and reclaim our language for several years now. In the words of language champion chuutsqa Layla Rorick (Hesquiaht First Nation):

Although our languages are in a critical state, we choose not to see them as dying or about to fail. As long as people strengthen language through continued use and effort, there is really nothing that can stop its resurgence (as cited in Gessner et al., 2014, p. 68).

Cultural and Pedagogical Inquiry, Fall 2018, 10(2), pp. 64-83

ISSN 1916-3460 @ 2018 University of Alberta

http://ejournals.library.ualberta.ca/index.php/cpi/index 


\section{Sharing of the Learnings}

In her doctoral research, Edōsdi (2012) used the term "learnings" instead of "data" when referring to the knowledge and wisdom that was shared with her by Tahltan co-researchers (fluent speakers, language teachers, educators, administrators, and language learners), as well as observations that she made. For this paper, learnings include all that we have learned from others and our observations that have led to the opening of our language nests. We have used "sharing of the learnings" to organize what we have learned about language nests in such a way that we hope will be helpful for others, in line with the methodology, Tahltan Voiceability (Edōsdi, 2012), and our Tahltan Language and Culture Framework (Edōsdi, 2012; TCG, 2018).

\section{The beginnings of language nests}

A language nest is early childhood language immersion programming that is conducted entirely in the Ancestral language of an Indigenous group (McIvor, 2005). It is likely that the very first language immersion early childhood program started with a group of Samoan and Cook Island mothers in 1973 (Utumpau, 1998). In the early 1980s, language nest programs started in Aotearoa (New Zealand), with their early-childhood language immersion program, Te Kōhanga Reo, being developed by the Māori community to have their children speak fluently in their language (King, 2001; Kirkness, 1998; Te Kōhanga Reo National Trust, 2010). Considered to be one of the most successful language revitalization programs globally, Te Kōhanga Reo has inspired other Indigenous nations and communities to follow their lead (King, 2001; Hinton, 2001b). One example was a small group of Hawaiian educators and community members who modeled their 'Aha Pūnana Leo (Hawaiian language nests) after the Māori Te Kōhanga Reo ('Aha Pūnana Leo, 2006; Hinton, 2001a; Warner, 2001). In Canada in the early 1980s, the first language nest program began in the Mohawk community of Kahnawake (Hoover, 1992; Richards and Burnaby, 2008) which was followed by Secwepemctsin program in Adams Lake, BC, started by Kathy Michel and Janice Billy in 1987 (Michel, 2005; Michel 2012).

\section{Why a Language Nest?}

From her research (Edōsdi, 2012), Edōsdi was told that there was a need for our language to be taught to our children at the crucial ages of newborn to five years of age. Her grandmother Julia Callbreath knew the importance of learning our Tāłtān language at an early age:

My dad was white; He never allowed my mother to teach us. They always say, "Let them learn English first, before they learn their own language." Well, that's not right. The younger you are, the easier it is to learn that language (as cited in Edōsdi, 2012, p. 193).

Tahltan educator David Rattray supported this sentiment: “The other thing that's really critical is when you look at language development you realize that these kids have to hear it before they're five years old" (as cited in Edōsdi, 2012, pp. 193-194). Tāłtān fluent speaker and retired language teacher Janet Vance added, "That's the best way to teach them, when they're little. You know why? Because it's in their blood" (as cited in Edōsdi, 2012, p. 194). Julia Callbreath, David Rattray, and Janet Vance are in good company as Fishman (1996), Lee (1996), and Stiles (1997) also concur that early childhood is the best time for language learning to occur. The Royal Commission on Aboriginal Peoples (1996) states that the first three years of a child's life are critical for laying the foundation of sound making and that "young children absorb information at a greater rate than at any other stage of life" (p. 447). According to linguist Marianne Ignace (1998), babies begin to acquire language within months of being born, and by 
the age of five, they have mastered the basic sound system and grammar of their mother tongue. Therefore, it is crucial to focus on early childhood programs that involve young children and their parents (Fishman, 1991). In the words of Patricia Louie:

From my training in Early Childhood Education, I learned that a baby who is four days old can distinguish its own language from other languages. The ideal learning years are from zero to eight and that's why it's so important to work with them when they are young. That's how important language is (as cited in Edōsdi \& Bourquin, 2016).

\section{How we started our nests}

While Edōsdi wrote about language nests in her doctoral dissertation, her true learnings came from several conversations with Dr. Kathryn Michel. Dr. Michel has worked within a language immersion setting since 1987 in the capacity of language nest coordinator and as curriculum developer for Chief Atahm School on the Adams Lake Band reserve near Chase, BC. She is currently completing a community research initiative with Chief Atahm School as part of a Social Sciences and Humanities Research Council of Canada's Partnership Grant entitled "First Nations Languages in the $21^{\text {st }}$ Century: Looking Back, Looking Forward" (Marianne Ignace Principal Investigator) with Simon Fraser University. As well, Chief Atahm School has partnered with Simon Fraser University and Nicola Valley Institute of Technology to offer an adult intensive Secwepemc language fluency program, with Kathryn being one of the lead instructors. Kathryn has stated that one of the school's mandates is to promote and support Indigenous language immersion initiatives. It was at the Chief Atahm Language Conference in 2013 where Edōsdi was fortunate enough to meet Kathryn. In a letter supporting funding for one of our language nests, Kathryn Michel wrote:

She [Edōsdi] approached me to ask me questions about starting a language nest. Over the course of a year her enthusiasm never wavered as she continued to seek me out to pick my brains on how to run a nest. Each time we met, it seemed she brought with her a new group of people from her community. She even took the initiative to respond to my challenge to "quit talking about it and just do it." The next time we met her community had set a date for starting a nest and were quite prepared to meet that challenges that lay ahead (personal communication, September 4, 2014).

Edōsdi attended the Chief Atahm School Language Conference in May 2013, along with Odelia Dennis, Sonia Dennis, and Verna Vance - newly hired members of the Tahltan Language and Culture Program team. Tāttān fluent speakers, Patrick and Theresa Etzerza, Patrick and Edith Carlick, and Angela Dennis also attended. Edōsdi had both read and heard about Kathy's language nest and how it was opened in 1987 (Michel, 2005; McIvor, 2005). At this conference, Edōsdi brought Angela Dennis to meet with Dr. Michel, which was followed by a meeting with Odelia. Edōsdi could sense that Kathy thought we should just do it, to not wait for the perfect conditions. Those initial conversations happened in May 2013, with several follow-up conversations in the fall to discuss logistics. This led to the opening of Dzimēs Chō T'oh in May 2014, with K'asba'e T'oh opening in December 2014.

Not only has Dr. Michel supported the opening of our nests, she has also had an opendoor policy for our language nest team members to visit her nest, with many of our team

Cultural and Pedagogical Inquiry, Fall 2018, 10(2), pp. 64-83

ISSN 1916-3460 @ 2018 University of Alberta

http://ejournals.library.ualberta.ca/index.php/cpi/index 
members visiting and observing since 2014, such as Angela Dennis, Odelia Dennis, and Patrick and Theresa Etzerza. In the words of Odelia Dennis:

The field visit allowed both myself and Angela [Dennis] to realize that a language nest is not a preschool. It's not any type of school. It's basically just a home setting and pretty much anyone can open a language nest as long as they have the support behind to do it. The structures, for instance, the house, the people, the fluent speakers. So for us to be able to see that happening really made us realize that it's possible that we could actually have a language nest in our territory (as cited in Morris, 2017, p. 89).

Natalie Chambers (2014) interviewed Kathy Michel for her doctoral research and discussed how communities can start nests.

She [Kathy] explained that individual communities must find their own way. Support for planning and the involvement of all individuals and other connected early learning programs may enable the development of unique strategies and bring together the skills and ways of knowing and interacting with children of fluent Elders, cultural workers and early childhood educators (as cited in Chambers, 2014, pp. 191-192).

\section{What does a language nest look like?}

What exactly does a language nest look like? Fluent Tāłtān speaker and language teacher Angela Dennis speaks about the importance of language nests to the revitalization of our language and emphasizes how it needs to be a home-like setting (FPCC, 2014; Edōsdi \& Bourquin, 2016).

But with the language nest, I think it's part of the foundation for bringing the language back. Because it's a home setting, you don't have a lot of restrictions on you. It's like living at your grandma's place. It's like Tsū tsū's house when you go to the language nest! It's a necessity, it's a necessity where, as First Nations people, if you really are interested in revitalizing your language. If you want to take that step where you're going to have that available to babies and their families, or even toddlers and their families, it paves the way to language learning (as cited in Edōsdi \& Bourquin, 2016).

Kathryn Michel's nest is an example of an early childhood immersion setting that emulates grandma's house. In her words:

If you walked in without the children there you would be hard pressed to realize that it was actually an early childhood center... you are wanting to feel like children are coming into the grandmother's house, and the grandmother's house does not look like the daycares I see... say, ok, let's just model this after granny's house and put the furniture in place and realistically make a few changes that make sense and then other than that is basically where they eat... need a lower table... a little sofa, [and] we have such a small space that everything is small (as cited in Chambers, 2014, p. 107).

Darrell Kipp, Blackfoot language champion, spoke about visiting the language nest in Hilo, Hawai'i:

We were brought to a one-classroom school where an older woman in an easy chair was speaking Hawai'ian to a group of children sitting around her on the floor. The beautiful 
sounds of the language resounded with seemingly every child speaking at once to the teacher. Off the side in a tiny kitchen was a middle-aged man preparing lunch in a large wok...The school visit reminded me of my years in a one-room reservation school and the beauty of the learning environment came back in an instant: "School at Gramma's house" (Kipp, 2009, pp. 2-3).

\section{Starting a language nest}

From the knowledge that Kathy shared, four key points have stayed with us. First, a language nest is not the same as a pre-school program or a daycare centre. It is very straight forward and simple. Elders and caretakers speak to the children in their Ancestral language while carrying out activities such as feeding, changing diapers, playing, and putting them down for a nap. Secondly, it is important to limit the number of children to the size of a family. Eight would be the maximum number of children you would want in a nest; if there are more children, it is too easy for English to start sneaking in. Thirdly, you want to have varying ages of children, like a family. For example, it's highly unlikely that you would have a family of six three-year olds, so try to avoid that scenario. Finally, when starting out, don't include older children ages four and five, unless they are familiar with learning the language. Otherwise, since they will be quite proficient in English, it is likely that they will dominate conversation and bring it back to English. Besides these four main points, we want to discuss the roles of people involved with the nest, as well as what our nests look like and where they reside in our communities.

\section{Roles}

\section{Language Mentors and Elders}

Tāłtān Language nest mentor, Theresa Etzerza states: "Our role...in the language nest is being the estū and estsiye, grandma and grandpa 'cause it's like a family setting" (Morris, 2017, p. 76). Tāłtān Language nest mentor Patrick Etzerza also spoke about their role in the language nest:

It's like ptarmigan's nest. See we're trying to nest. We're trying to nurture these young, our young children. We're trying to nurture, that's why we say we have a home setting for our language, so that we've got the kitchen, the bedroom, nintē or dinbeda or whatever (Morris, 2017, p. 74).

Patricia Louie has stated: "One of the things that I really want to encourage is that the Elders get more involved in coming to our languages nests. The more conversation going in our language is much better for us, and for the children" (as cited in Edōsdi \& Bourquin, 2016).

\section{Staff}

Capacity has been, and continues to be, a big issue when it comes to revitalizing our language in our three communities. When we opened the nest in Łuwechōn in May 2014, Odelia was travelling from her home in Tātl'ah to work in the nest in Łuwechōn, which is approximately $84 \mathrm{~km}$ away, or just under one hour of driving time. In the winter, the time to drive takes even longer. Once we opened the nest in Tātl'ah, Odelia was working in both nests, travelling back and forth between the two communities. Patricia Louie was hired in December of 2014, the same month that we opened the nest in Tātl'ah. While Odelia was still travelling back and forth, she

Cultural and Pedagogical Inquiry, Fall 2018, 10(2), pp. 64-83

ISSN 1916-3460 @ 2018 University of Alberta

http://ejournals.library.ualberta.ca/index.php/cpi/index 
had the support of Patricia in the nest in Łuwechōn. As well, Patricia would often travel to work in the nest in Tātl'ah.

For each community, we have hired a language and culture coordinator and a language and culture assistant. Both staff members are required to work in the nest, but their language and culture responsibilities go beyond.

\section{Parents and Family}

For newborns and toddlers to really learn our language, besides being used in language nests, our language also needs to be spoken in their homes (FPCC, 2014.) Part of the reason why nests are modelled after home-like settings is to ensure that children don't see our language as something that is only used in a school setting. To ensure that language is also spoken in their homes, our program is working to support parents to increase their language proficiency. We have increased the number of opportunities for parents and siblings to learn language, such as parent evening sessions and community evening sessions. We have noticed that once parents have the skills to speak language at home, the children are more willing to speak language in the nest. Odelia Dennis had said,

So now that we have children that are learning the language in the language nests, I really believe it's important for the parents to start learning the language. Because we have the Elders who know the language and some speak fluently and then we have the children who are understanding the language and are starting to speak the language. I feel that by bridging the gap between the Elders and the children by having the parents learn the language, we're promoting the intergenerational transmission of the language where the parents pass the language onto their children. I feel that it's very important for adults of childbearing age to learn the language (as cited from Edōsdi \& Bourquin, 2016).

It is important to have the family of the children involved in language learning, so an emphasis is being placed on evening language sessions (once per week) for parents and siblings, as well as having parents coming into the nest for 30 minutes per week. There are family luncheons that happen once per month.

\section{Language Nest Spaces}

Regarding the two nests that we have opened to-date, we have found that we have had to be creative and adaptable, while also building relationships with other community organizations.

In Łuwechōn, we worked out an arrangement with the Iskut Band Council to share a house being used by the Social Development Program with the Youth Program. It was set up like a home and was a wonderful setting for the nest. In September 2016, the house was no longer available for our use, so our program moved to the Iskut Valley Health Services Head Start Program building. It was challenging to set up a home environment atmosphere, but we found a way, while sharing the space with the Head Start Program. The experience of having our nest at the Head Start Program benefited staff from both the nest and Head Start, as well as all the children, in terms of relationship building and language learning. In May 2018, the Iskut Band let us know that we could rent the original house that our nest opened in, with the house now being dedicated specifically to language revitalization programming. 
For the nest in Tātl'ah, we worked out an arrangement with the Pregnancy Outreach Program to use the house they are occupying in the afternoons. Because we are renting a house from an organization that provides services to families with young children, the setting has been ideal for a language nest.

\section{Language Houses}

One goal of our Tahltan Language and Culture Program is for each community to have a home for our language programs; a safe place for our language to flourish. In April 2018, this goal has been fulfilled in Łuwechōn. We see language houses as a place for Elders, infants, toddlers, parents, and other language learners to connect and build relationships while learning language. We are working towards having language houses in both Tâtl'ah and Tlēgo'īn. ${ }^{i}$

\section{Next Steps}

Regarding our Language and Culture Program, we feel that we have done a lot in terms of creating opportunities for our people to speak Tâłtān but more is needed for the nests.

\section{Community Support and Awareness}

As a nation, we must have the will to revitalize our language. This can only come about if our people are aware of how important our language is to us as a people, and how fundamentally our language is connected to our land, our Elders, our Ancestors, and our Tahltan identity (Edōsdi, 2012). Part of our Tahltan Language and Culture Framework includes the healing, wellbeing, and resiliency of our people. From what we have learned about the connection between language and identity, language is seen to be healing (Chandler et. al, 1998; Hallett et al., 2007; McIvor et al., 2009; Edōsdi, 2012; Jenni et al., 2017). We have observed that in both our adult immersion program and in our nests. However, we also know that many of our people are still suffering from the trauma of Residential schools and from the impacts of colonization and assimilation. We need to find a way to work with our people who have not been able to overcome that pain and trauma. The awareness of what was taken from us - what was stolen from us - needs to be discussed and our program needs to be able to answer the following questions: How can we raise awareness with our people about why our language has so few speakers now? How can we can raise awareness with our people about why our language is so crucial to who we are as Tahltan people? How can we raise awareness with our people about the language revitalization work that is going on?

\section{Promotion of the Language}

A big part of community awareness includes promotion of the language, which involves raising "the consciousness level of our people" (Kirkness, 2002, p. 18). In the words of Cree scholar Verna Kirkness (2002), to save Indigenous languages, "there is a need to ensure that our people know why our languages are nearing extinction and why our languages are so important to our lives and to who we are" (p. 18). We need to encourage and motivate our people to use the language in all areas of their lives. This includes using the language in the workplace, at community gatherings, and for everyday activities.

It is also important for non-Tahltans, and more generally, non-Indigenous people, to understand how crucial it is to preserve and revitalize Indigenous languages that were here

Cultural and Pedagogical Inquiry, Fall 2018, 10(2), pp. 64-83

ISSN 1916-3460 @ 2018 University of Alberta

http://ejournals.library.ualberta.ca/index.php/cpi/index 
before Canada as a nation was born. In the words of Dr. Lorna Williams, Lil'wat from the St'at'yem'c First Nation:

It's important to recognize and acknowledge that when people made or make their homes on the lands we now call Canada, that they take on the heritage of the languages located on those lands. It's extremely important that the public recognizes all Indigenous languages as their heritage; then governments must respond to ensure the knowledge and wisdom embedded in the languages are protected. These languages exist nowhere else in the world (as cited in Sharpe, 2011, p. 4).

The language must be spread throughout the community to capture the interest of community members. We need to continue to spread the language in any way we can, both formally (e.g., posting videos on social media; creating signage in public places; game nights; tea and bannock, etc.) and informally (e.g., interacting in Tāłtān; holding mini-lessons, etc.).

\section{New Adult Speakers}

The Tahltan Nation has approximately 20 fluent first language speakers, with several of them being willing and able to work with us as mentors in our immersion programs, both in the nest and in our university Diploma in Indigenous Language Revitalization Program. Due to the advanced age of most of our mentors, as Chambers (2014) states: “...in communities where fluent Elders are few, very elderly or in poor health, the future of the language may depend upon the creation of new adult speakers through language courses" (p. 188). We have been doing that in our adult immersion program, and we will continue to provide opportunities for adults to increase their proficiency in our language in immersion settings. For our nests to continue and flourish, we need to create new adult speakers who can not only work in our nests, but can also carry out the work outlined by our Tahltan Language and Culture Framework (Edōsdi, 2012, TCG, 2018) to revitalize and reclaim our language.

\section{Future Research}

We agree with Chambers (2014) in terms of the need for more research that will inform the language revitalization work that is being carried out in language nests.

...more research is required that explores the impact of language nest programs in communities with severely endangered languages where language nest children are learning their Indigenous language as a second language... (p. 193).

\section{Evaluation Plan}

Since we began our language nest planning in 2013, the evaluation of both the program and language proficiency has been a goal of our program. Morris (2017) has made a similar recommendation for our language nest program:

Research to assess and evaluate our language nests should be a priority. This would provide the administrators, language mentors, and parents with valuable information about the effectiveness of the nests, as well as identify the successes and risk factors. This research could identify better ways to support language nest workers, language mentors, parents, and children, as well as ways to assess the language development and progression of the nest workers, language mentors, children, and parents (pp. 98-99). 


\section{Language Proficiency Evaluation}

In terms of language proficiency, the evaluation will focus on the children being able to both understand and communicate in Tāttān. Some examples would be giving the children commands with little or no gestures and observing their reactions. Examples of commands would be: "Wash your hands" and "Sing with us." Other examples would be asking simple questions that would focus on the children speaking, such as "What would you like to eat?" These evaluations would be carried out several times throughout the program to assess the development and progression of the children's acquisition of the Tâłtān language. Language evaluation could also be carried out with parents, siblings, fluent speakers, staff members, and others who have been involved with the language nest to assess their development and progression of the use of the language.

\section{Program Evaluation}

We plan on carrying out interviews with parents, siblings, staff, Elders, fluent speakers, and other individuals involved with the program to find out how successful they feel the program has been. Surveys evaluating understanding and speaking of the language would be developed for parents, fluent speakers and caretakers. During the evaluation of the program, we will continue our efforts for determining why the children choose to answer questions in the English language even if they may know the answer in Tāłtān.

\section{Other Research}

While we plan on carrying out research for the evaluation of our nests, we also know that there is more research that needs to be done on immersive early language learning. Natalie Chambers completed her doctoral research in 2014, with a focus on language nests. In writing about her research, she stated: "This research is presented in service to the reclamation of early learning, Indigenous languages, and the intergenerational ways of knowing and being" (Chambers, 2014, p. ii). She has given recommendations for future research that we agree with.

Chambers (2014) suggests that studies be done that explore the relationship between children and Elders and adults, as well as the intergenerational transmission of knowledge and wisdom:

My research findings demonstrate the role of language nests in increasing the access of Indigenous children to fluent Elders and other adults who are role models of cultural resilience and continuity. Qualitative research with young children is needed to explore how nest children and young graduates understand their relationships with fluent Elders and nest workers, and what roles these adults play in contributing to the development of a strong Aboriginal identity early in life (p. 194).

Creating environments where Indigenous languages can thrive is not an easy endeavor. It is important for language champions from all nations find ways to network and share knowledge and experiences. This was key for us in terms of starting our nests, and we will forever be grateful to Dr. Kathryn Michel.

My research shows the power of bearing witness to other Indigenous peoples living their languages in the language nests through site visits, networking, conference or video presentations. My findings demonstrate that there is a need for more information on

Cultural and Pedagogical Inquiry, Fall 2018, 10(2), pp. 64-83

ISSN 1916-3460 () 2018 University of Alberta

http://ejournals.library.ualberta.ca/index.php/cpi/index 
language nests in Canada since raised awareness at the community level may generate more support for language nest development. (Chambers, 2014, pp. 181-182)

Finally, Chambers (2014) has suggested that "the roles of language nests in providing quality culturally informed nurturing during early childhood could be explored with a focus on impacts on the social-emotional competence of Indigenous children" (p. 193). In terms of socioemotional competence from Indigenous perspectives, this includes "cultural, social, emotional, and mental wellness that contribute to the development of a strong identity" (Tremblay et al., 2013, p. 11). In the words of Angela Dennis, Tāłtān language educator, mentor, and fluent speaker:

My belief is that our language is the language of the heart. This is where you speak it from. And it's a gift that's given to us from the Creator through our Ancestors. And I believe it's something that we should cherish because it's part of our identity (as cited in Edos̄di \& Bourquin, 2016).

\section{Conclusion}

By using an Indigenous methodology, Tahltan Voiceability, we set the stage for research that is useful, relational, and transformative by giving voice to our teachers (Edōsdi, 2012, 2017). Relationality has been critical in the success of our language nests, both in what we have learned, but also in the ways in which we are now sharing these learnings, in keeping with our Tahltan Language and Culture Framework.

The Tahltan Language and Culture Program continues to have an impact on the healing, wellbeing, and resiliency of our people and communities in terms of building capacity through language governance, language programming, documentation, and the training of teachers, researchers, and other language workers. Specific to language nests, we have connected Elders and language learners of all ages, providing ways to build relationships between the generations. From Edōsdi's (2012) doctoral research, she learned from several Tahltan educators that language is an essential part of identity and strong self-esteem. In response to the question, "Why is it important for our children to learn the Tāłtān language?", this was Tahltan educator and artist Loretta Quock-Sort's answer:

It is important for our children to learn the Tâłtān language because it is who they are, where they come from, and it needs to be passed down from this generation to the next. If they don't have their language, how can they be proud of who they are? Without our language and culture, who are we as a people? (as cited in Edōsdi, 2012, p. 118).

Sonia Dennis, Tahltan educator and language learner, responded to the question in a similar fashion:

I feel that it is important for our children to know because this is who we are, people of the land, our roots are instilled here. And the more we detach from it, the more we lose sight of the strong Nation that we come from. I want my children to know who we are and be proud of it. Our Ancestors have walked this land and kept it intact so that our children could see the beauty of our people. Our language is one of many great aspects of being Tahltan, it belongs to us, it is who we are (as cited in Edōsdi, 2012, p. 119). 
Patricia Louie shared an interaction between a language nest staff member and a young child in the nest, which highlights the connection between language and identity, and how language nests are having a positive effect on our children.

Child: "You are a Tahltan girl, right?"

Staff member: "Why do you say that?"

Child: "Because you speak Tāłtān and teach Tāłtān. When I grow up, I'm going to be a Tahltan girl!"

\section{Endnote:}

${ }^{\mathrm{i}}$ In terms of Tahltan Voiceability and the Tahltan Language and Culture Framework, it is crucial that we share what we have learned with others. For more information about administrative components (e.g., funding, budgets, job descriptions), activities, development of learning materials, successes and challenges, contact the authors and/or visit tahltanlanguage.com.

Cultural and Pedagogical Inquiry, Fall 2018, 10(2), pp. 64-83

ISSN 1916-3460 () 2018 University of Alberta

http://ejournals.library.ualberta.ca/index.php/cpi/index 


\section{References}

'Aha Pūnana Leo. (2006). Hi'ipēpē - Infant Program. Retrieved from: http://www.ahapunanaleo.org/index.php?/programs/native_speaker_infant_toddler_language nests/

Amrhein, H., Gessner, S., Herbert, T., Daniels, D., Lappi, M., Hamilton-Evans, D., \& Wadsworth, A., (2010). Report on the status of BC First Nations Languages 2010. Brentwood Bay, BC: First Peoples' Cultural Council. Retrieved from: http://www.fpcc.ca/files/PDF/2010-report-on-the-status-of-bc-first-nations-languages.pdf

Baloy, N. J. (2008). Exploring the potential for Native language revitalization in an urban context: Language education in Vancouver. (Unpublished Master's Thesis). University of British Columbia, Vancouver, BC.

Chamberlin, J. E. (1999). Doing things with words: Putting performance on the page. In L. J. Murray and K. Rice (Eds.), Talking on the page: Editing Aboriginal Oral Texts (pp. 69-90).

Chambers, N. A. (2014). "They all talk Okanagan and I know what they are saying." Language nests in the early years: Insights, challenges and promising practices (Unpublished Doctoral Dissertation). University of British Columbia, Kelowna, BC. Retrieved from: http://open.library.ubc.ca

Chambers, N. A. (2015). Language nests as an emergent global phenomenon: Diverse approaches to program development and delivery. The International Journal of Holistic Early Learning and Development, 1, 25-38.

Chandler, M. J., \& Lalonde, C. E. (1998). Cultural continuity as a hedge against suicide in Canada's First Nations. Transcultural Psychiatry, 35, 191-219.

Edōsdi/Thompson, J. C. (2012). Hedekeyeh Hots'ih Kāhidi - "Our Ancestors are in us": Strengthening our voices through language revitalization from a Tahltan worldview (Unpublished Doctoral Dissertation). University of Victoria, Victoria, BC.

Edōsdi/Thompson, J. C. (2017). The artistry of research: The strength and stability of voice. In K. Staikidis, \& C. Ballengee-Morris (Eds.), Transforming our practices: Indigenous art, pedagogies, and philosophies. Reston, VA: National Art Education Association Press.

Edosdi /Thompson, J. C., Bourquin, M. (Producers), \& Bourquin, M. (Director). (2016). Dah Dżāhge Nodeșidē: We Are Speaking Our Language Again. [Video/DVD]. Dease Lake, BC: Tahltan Central Government. Retrieved from: https://vimeo.com/217095185

First Nations Health Authority. (2018). Aboriginal Head Start On-Reserve. Retrieved from: http://www.fnha.ca/what-we-do/maternal-child-and-family-health/aboriginal-head-start-on$\underline{\text { reserve }}$

First Peoples' Cultural Council. (2014). The language nest story: As told by Kathy Michel. Retrieved from: https://www.youtube.com/watch?v=ffUTiwsRlag 
Fishman, J. (1991). Reversing language shift: Theoretical and empirical foundations of assistance to threatened languages. Clevedon: Multilingual Matters Ltd.

Fishman, J. (1996). What do you lose when you lose your language? In G. Cantoni (Ed.), Stabilizing Indigenous languages (pp. 80-91). Flagstaff, Arizona: Northern Arizona University.

Gessner, S., Herbert, T., Thorburn, B., \& Wadsworth, A. (2014). Report on the status of BC First Nations Languages 2014. Brentwood Bay, BC: First Peoples' Cultural Council. Retrieved from: http://www.fpcc.ca/files/PDF/Language/FPCC-LanguageReport-141016-WEB.pdf

Hallett, D., Chandler, M. J., \& Lalonde, C. E. (2007). Aboriginal language knowledge and youth suicide. Cognitive Development, 22(2007), 392-399.

Hinton, L. (2001a). An introduction to the Hawaiian language. In L. Hinton, \& K. Hale (Eds.), The green book of language revitalization in practice (pp. 129-132). San Diego, CA: Academic Press.

Hinton, L. (2001b). Language planning. In L. Hinton, \& K. Hale (Eds.), The green book of language revitalization in practice (pp. 51-59). San Diego, CA: Academic Press.

Hoover, M., \& the Kanien'kehaka Raotitiohkwa Cultural Center. (1992). The Revival of the Mohawk Language in Kahnawake. Canadian Journal of Native Studies, 12(2), 269-287.

Ignace, M. B. (1998). Handbook for Aboriginal language program planning in British Columbia. Vancouver, BC: First Nations Education Steering Committee.

Jenni, B., Anisman, A., McIvor, O., \& Jacobs, P. (2017). An exploration of the effects of Mentor-Apprentice Programs on mentors' and apprentices' wellbeing. International Journal of Indigenous Health, 12(2), 25-42.

King, J. (2001). Te kohanga reo: Maori language revitalization. In L. Hinton, \& K. Hale (Eds.), The green book of language revitalization in practice (pp. 119-128). San Diego, CA: Academic Press.

Kipp, D. (2009). Encouragement, guidance and lessons learned: 21 years in the trenches of Indigenous language revitalization. In J. Reyhner, \& L. Lockard (Eds.), Indigenous language revitalization: Encouragement, guidance and lessons learned (pp. 1-9). Flagstaff, Arizona: Northern Arizona University.

Kirkness, V. (1998). The critical state of Aboriginal languages in Canada. Canadian Journal of Native Education, 22(1), 93-108.

Kirkness, V. (2002). The preservation and use of our languages: Respecting the natural order of the creator. In B. Burnaby, \& J. Reyhner (Eds.), Indigenous languages across the community (pp. 17-23). Flagstaff, Arizona: Northern Arizona University.

Lee, P. (1996). Cognitive development in bilingual children: A case for bilingual instruction in early childhood education. Bilingual Research Journal, 20(3\&4), 499-522.

Cultural and Pedagogical Inquiry, Fall 2018, 10(2), pp. 64-83

ISSN 1916-3460 @ 2018 University of Alberta

http://ejournals.library.ualberta.ca/index.php/cpi/index 
McIvor, O. (2005). Building the nests: Indigenous language revitalization in Canada through early childhood immersion programs (Unpublished Master's Thesis). University of Victoria, Victoria, BC. Retrieved from: http://dspace.library.uvic.ca

McIvor, O. (2006). Language nest programs in BC: Early childhood immersion programs in two First Nation communities. Practical questions answered and guidelines offered. Retrieved from: http://www.fpcc.ca/files/PDF/language-nest-programs_in_BC.pdf

McIvor, O., \& Napoleon, A. (2009). Language and culture as protective factors for at-risk communities. Journal of Aboriginal Health, November, 6-25.

Michel, K. (2005). You can't kill coyote: Stories of language healing from Chief Atahm School Secwepemc language immersion program (Unpublished Master's Thesis). Simon Fraser University, Burnaby, BC. Retrieved from: http://summit.sfu.ca

Michel, K. (2012). Trickster's path to language transformation: Stories of Secwepemc immersion from Chief Atahm School (Unpublished Doctoral Dissertation). University of British Columbia, Vancouver, BC. Retrieved from: http://open.library.ubc.ca

Morris, K. J. A. (2017). K'asba'e T'oh: Sustaining the intergenerational transmission of Tāttān. (Unpublished Master's Thesis). University of Victoria, Victoria, BC. Retrieved from: http://dspace.library.uvic.ca//handle/1828/8544

Morris, K. J. A. (2018). Using language nests to promote the intergenerational transmission of Tāłtān. In J. Markides, \& L. Forsythe (Eds.), Looking back and living forward: Indigenous research rising up (pp. 73-80). City: Leiden, Netherlands: Brill. Series: Transgressions: Cultural Studies and Education, Volume:125

Okura, E. K. (2017). Language nests and language acquisition: An empirical analysis. (Unpublished Doctoral Dissertation). University of Hawaii at Manoa, Honolulu HI. Retrieved from: http://ling.hawaii.edu/wp-content/uploads/Okura_Eve_Dissertation_Draft1.pdf

Public Health Agency of Canada (2016). Aboriginal Head Start in urban and northern communities. Retrieved from: http://cbpp-pcpe.phac-aspc.gc.ca/aboriginalwtt/aboriginalhead-start-in-urban-and-northern-communities/

Richards, M., \& Burnaby, B. (2008). Restoring Aboriginal languages: Immersion and intensive language program models in Canada. In T. W., Fortune, and D. J. Tedick, (Eds.), Pathways to multilingualism: Evolving perspectives on immersion education, 66. Multilingual Matters.

Royal Commission on Aboriginal Peoples. (1996). Volume 3: Gathering strength: Report of the Royal Commission on Aboriginal Peoples. Ottawa: Minister of Supply and Services.

Sharpe, T. (2011). It's common knowledge in communities. The Ring, 35(6), 1, 4. Retrieved from: https://www.uvic.ca/news/topics/2011+it--s-common-knowledge-in-communities+ring

Stiles, D. B. (1997). Four successful Indigenous language programs. In J. Reyhner (Ed.), Teaching Indigenous languages (pp. 248-262). Flagstaff, Arizona: Northern Arizona University.

Cultural and Pedagogical Inquiry, Fall 2018, 10(2), pp. 64-83

ISSN 1916-3460 @ 2018 University of Alberta

http://ejournals.library.ualberta.ca/index.php/cpi/index 
Tahltan Central Council (TCC). (2013). Socio-Cultural Working Group: Language and Culture Report, Volume 1.

Tahltan Central Government. (2018). Tahltan Central Government 2017/2018 Annual Report. Retrieved from: http://www.Tahltan.org/newsletters-2/

Te Kōhanga Reo National Trust. (2010). History. Retrieved from: https://www.kohanga.ac.nz/history/

Tremblay, M., Gokiert, R., Georgis, R., Edwards, K., \& Skrypnek, B. (2013). Aboriginal Perspectives on Social-Emotional Competence in Early Childhood. The International Indigenous Policy Journal, 4(4), 2.

United Nations. (2008). United Nations Declaration of the Rights of Indigenous Peoples. Retrieved from: http://www.un.org/esa/socdev/unpfii/documents/DRIPS_en.pdf

Utumapu, T.L.P. (1998). O le poutu: Women's roles and Samoan language nests. (Unpublished Doctoral Dissertation). University of Auckland, Auckland.

Warner, S. L. N. (2001). The movement to revitalize Hawaiian language and culture. In L. Hinton, \& K. Hale (Eds.), The green book of language revitalization in practice (pp. 133144). San Diego, CA: Academic Press.

Wilson, S. (2001). What is Indigenous research methodology? Canadian Journal of Native Education, 25(2), 175-179.

Cultural and Pedagogical Inquiry, Fall 2018, 10(2), pp. 64-83

ISSN 1916-3460 @ 2018 University of Alberta

http://ejournals.library.ualberta.ca/index.php/cpi/index 